\title{
Urgensi Fatwa MUI dalam Pembangunan Sistem Hukum Ekonomi Islam di Indonesia
}

\author{
Andi Fariana \\ (Asian Banking-Finance and Informatics Instutute of Perbanas -ABFII Perbanas, \\ Jl. Perbanas, Karet Kuningan Setiabudi Jakarta 12940, Email: \\ andi.fariana@mail.abfiiperbanas.ac.id)
}

\begin{abstract}
Abstrak:
Fatwa tidak sama dengan hukum positif yang memiliki kekuatan mengikat bagi seluruh warganegara, namun fatwa dapat memiliki kekuatan mengikat setelah ditransformasi ke dalam peraturan perundang-undangan. Fatwa yang dikeluarkan oleh DSN-MUI (Dewan Syariah Nasional Majelis Ulama Indonesia) kurang lebih sebanyak 107 fatwa dan telah memberi kontribusi positif terhadap regulasi sistem hukum ekonomi syariah. Fatwa DSN-MUI menjadi bagian penting dalam sistem Hukum Republik Indonesia yang berdasarkan pada Pancasila sila pertama adalah Ketuhanan Yang Maha Esa dan salah satu dari the living law-nya adalah Hukum Islam. Metode penelitian yuridis normatif ini dilakukan dengan pendekatan deskriptif analitis, yaitu menggambarkan secara sistematis, faktual dan akurat, segala fakta dan permasalahan yang diteliti dikaitkan dengan teori-teori hukum dan dengan (1) pendekatan perundangundangan (statute approach), (2) pendekatan sejarah (hystorical approach), (3) pendekatan politis (Political approach). Selanjutnya, data yang diperoleh dianalisis secara yuridis kualitatif dengan memperhatikan sistem hukum yang berlaku dan kemudian dilakukan penafsiran.
\end{abstract}

\section{Kata-kata Kunci:}

Fatwa MUI, Ekonomi Syariah, Sistem Hukum Ekonomi Islam

\begin{abstract}
:
Fatwa is not the same as the state law which has binding force for all citizens, but it may have binding force after being transformed into a legislation. Fatwas that have been issued by the DSN-MUI (the National Sharia Council of Indonesian Ulama Council) are approximately 107 fatwas and have contributed positively to the regulation of the legal system of Islamic economics. Fatwa of the DSN-MUI has became an important part in the law system of the
\end{abstract}


Republic of Indonesia which is based on Pancasila (The Five Principles) in which the first principle of the Pancasila is the Almighty God and one of its living law is Islamic law. This research applies normative legal method with analytical descriptive approach, which describes systematically, factually and accurately all the facts and problems being studied. This is done by associating them with theories of law through (1) statute approach, (2) hystorical approach, and (3) Political approach. Next, the data obtained are analyzed through juridical qualitative method by considering the legal system before being interpreted.

Key Words:

MUI (Indonesian Ulama Council) Fatwa, Islamic Economics, Islamic Economic Legal System

\section{Pendahuluan}

Subsistem keuangan yang diwakili oleh dunia perbankan mengalami krisis pada dua atau tiga dekade terakhir. Krisis tersebut telah melahirkan suatu kebutuhan akan sebuah "arsitektur baru" dalam sistem keuangan untuk mencegah efek atau dampak yang akan ditimbulkan atau paling tidak akan memperkecil frekuensi krisis. Arsitektur baru tersebut saat ini dikenal sebagai ekonomi Islam atau ekonomi syariah (Istilah yang dipergunakan di Indonesia).

Ekonomi Islam mulai bangkit pada Tahun 1930 dan mengalami puncaknya pada Tahun 1960-an. Tumbuhnya ekonomi Islam diawali di Pakistan dengan didirikannya bank local dengan prinsip tanpa bunga, kemudian dilanjutkan dengan Mesir yang mendirikan Mit Ghamir Local Saving. Hal tersebut terus berlanjut sampai saat ini, dan fenomena ekonomi Islam telah menjadi perhatian para ilmuwan muslim abad XX.

Sebagaimana sistem ekonomi internasional, perbankan merupakan subsistem terpenting. Demikian juga halnya dengan sistem ekonomi nasional. Ketika dunia semakin mengglobal dan bersamaan dengan itu perkembangan dunia bisnis juga menyertainya, hal ini menimbulkan ketergantungan kepada perbankan dalam aktivitas bisnis. Pertumbuhan perbankan syariah di 
Indonesia berkembang cukup pesat. ${ }^{1}$ Data yang ada menunjukkan bahwa pertumbuhan Bank Syariah dan unit usaha syariah di Indonesia terus meningkat. Berdasarkan penilaian dari Global Islamic Financial Report (GIFR) tahun 2011, Indonesia menduduki urutan keempat sebagai Negara yang memiliki potensi dan kondusif dalam perkembangan industri keuangan syariah setelah Iran, Malaysia dan Saudi Arabia. ${ }^{2}$ Per September 2016 total asset perbankan syariah mencapai Rp. 331.76 triliun dan pangsa pasar perbankan syariah terhadap industri perbankan nasional mencapai 5.3 persen. ${ }^{3}$ Bahkan pertumbuhan perbankan syariah pada Tahun 2016 mencapai 12 persen secara tahunan (year on year) sementara pertumbuhan perbankan konvensional hanya mencapai 7,2 persen, walau pangsa pasarnya stagnan namun secara keseluruhan pertumbuhan ini patut disyukuri. Selain pertumbuhan yang mengembirakan, Indonesia diklaim sebagai perbankan ritel syariah terbesar di dunia dengan lebih dari 18 juta nasabah dan lebih dari 4.500 kantor cabang pada Tahun 2015.4

Hal positif dari tumbuh dan berkembangnya perbankan syariah adalah ikut pula tumbuh dan berkembang unit usaha syariah pada Bank konvensional yang kesemuanya secara simultan memberi dampak bagi tumbuhnya berbagai kegiatan dalam bidang ekonomi khususnya keuangan yang bernuansa syariah seperti asuransi, BMT, penjaminan, pegadaian, termasuk hotel, MLM, dan pendidikan. ${ }^{5}$

Pertumbuhan kegiatan bisnis yang bernuansa syariah, secara umum merupakan salah satu pendukung gerak pertumbuhan ekonomi nasional dan dalam kondisi yang terus tumbuh tentu akan diikuti berbagai persoalan. Salah satu persoalan penting adalah, diperlukannya landasan hukum untuk berbagai aktivitas bisnis (yang terus tumbuh beragam) baik dalam bidang perbankan maupun dalam

1 Yuslam Fauzi, Perospek Ekonomi Syariah, makalah dalam seminar Nasional IAEI bekerjasama dengan ABFII Perbanas, (Jakarta, 20 Februari 2013).

2 Halim Alamsyarh (Deputi Gubernur BI), Perkembangan dan Prospek Perbankan Syariah Indonesia, Tantangan Dalam Menyongsong MEA 2015, ceramah ilmiah IAEI, (Jakarta, 13 April 2012)

3 Achmad K. Permana (Sekretaris Jenderal Asbisindo), compass.co.id, ( 21 November 2016)

4 Agus Martowardojo (Gubernur Bank Indonesia), Syariah Economic Festival, Surabaya, kompas, .co.id, (27 Oktober 2016)

${ }_{5}$ Yuslam Fauzi, op.cit 
bidang bisnis syariah lain. Sampai saat ini, Bank Indonesia dan Otoritas Jasa Keuangan (OJK) mengandalkan MUI (Majelis Ulama Indonesia) untuk melahirkan fatwa dalam masalah-masalah yang menyangkut aktivitas bisnis syariah dan berkaitan dengan persoalan fiqih, sementara disisi lain MUI bukan merupakan lembaga/institusi resmi Negara yang dapat melahirkan regulasi. Disinilah arti penting kajian ini karena berkaitan dengan kewenangan MUI dalam melahirkan fatwa yang dapat menjadi rujukan dalam regulasi dalam aktivitas bisnis syariah serta berkaitan dengan kedudukan fatwa dalam sistem hukum nasional.

Tulisan ini merupakan kajian hukum normatif (yuridis normatif). Identifikasi masalah tulisan ini yaitu bagaimanakah urgensi fatwa MUI dalam pembangunan sistem hukum ekonomi syariah? Pendekatannya yaitu: (1) pendekatan perundang-undangan (statute approach), (2) pendekatan sejarah (hystorical approach), (3) Pendekatan politis (Political approach). ${ }^{8}$

\section{Negara Hukum, Politik Hukum Islam dan Pembangunan Sistem Hukum Ekonomi Islam}

Sejak Republik Indonesia merdeka pada tanggal 17 Agustus 1945, keberadaan sistem hukum Nasional masih dipertanyakan. Apakah sistem hukum nasional telah terbentuk dan apakah sistem hukum nasional tersebut. Tenku M. Radhie menyebutkan bahwa pemerintah telah menetapkan kebijakan untuk memanfaatkan sistem hukum yang ada di dalam masyarakat untuk pembentukan sistem hukum nasional. Ketiga sistem hukum yang hidup dan berkembang di dalam masyarakat adalah Hukum Islam, Hukum Adat dan Hukum Barat ${ }^{6}$.

Negara hukum atau rechsstaat sudah popular sejak abad ke 19 di Eropa. Cita Negara Hukum untuk pertama kali di kemukakan oleh Plato dan kemudian dipertegas oleh Aristoteles yang menyatakan bahwa yang memerintah dalam suatu negara bukanlah manusia tetapi pikiran yang adil dan kesusilaan yang menentukan baik dan

8 Soerjono Soekanto, Penelitian Hukum Normatif, (Jakarta: Raja Grafindo Persada, 2012), 14 dan 52.

6 Imam Syaukani dan A. Ahsin Thohari, Dasar-dasar Politik Hukum, (Jakarta: Raja Grafindo Persada, 2004), 65 
buruk suatu hukum. ${ }^{7}$ Menurut Aristoteles, suatu negara yang baik ialah Negara yang diperintah dengan konstitusi dan berkedaulatan hukum, ia mengatakan: Constitutional rule in a state is closely connected, also with the requestion wheter is better to be rulled by the best men or the best law, since a goverrment in accordinace with law. 8 Aristoteles juga mengemukakan tiga unsur dari pemerintahan berkonstitusi. Pertama: pemerintah dilaksanakan untuk kepentingan umum. Kedua: Pemerintahan dilaksanakan menurut hukum yang berdasarkan ketentuan-ketentuan umum, bukan hukum yang dibuat secara sewenang-wenang yang mengesampingkan konversi dan konstitusi. Ketiga: Pemerintahan berkonstitusi juga dilaksanakan atas kehendak rakyat. ${ }^{9}$

Ciri-ciri rechsstaat adalah: 10

1. Memiliki undang-undang dasar atau konstitusi yang memuat ketentuan tertulis tentang hubungan antara penguasa dengan rakyat

2. Terdapat pembagian kekuasaan Negara

3. Mengakui dan melindungi hak-hak kebebasan rakyat

Beberapa hal yang mewakili sebagai ciri Negara hukum adalah adil, keadilan sosial karena salah satu dari tujuan negara hukum adalah dicapai keadilan.11Pengertian keadilan dalam Negara hukum Indonesia adalah bukan hanya keadilan hukum tetapi juga keadilan sosial.

Sri Soemantri mengemukakan unsur-unsur terpenting dari Negara hukum yaitu:12

1. Pemerintah dalam melaksanakan tugas dan kewajibannya harus berdasar atas hukum atau perundang-undangan;

7Ni'matul Huda, Negara Hukum, Demokrasi dan Judicial Review, (Jogyakarta: UII Press, 2005), hlm 1

${ }^{8}$ George Sabine, A History of Political Theory, (London: George G. Harrap \& CO.Ltd. , 1995), hlm. 92

9ibid

${ }^{10} \mathrm{Ni}^{\prime}$ matul Huda, op.cit., hlm 9

11Dahlan Thalib, Kedaulatan Rakyat Negara Hukum dan Hak-hak Asasi Manusia, Kumpulan Tulisan dalam rangka 70 Tahun Sri Soemantrri Martosoewignyo, (Jakarta: Media Pratama, 1996), hlm. 25

12Sri Soemantri, Bunga Rampai Hukum Tata Negara Indonesia, (Bandung: PT Alumni, 1992), hlm. 29-30 
2. Adanya jaminan terhadap hak asasi manusia (warganegara);

3. Adanya pembagian kekuasaan;

4. Adanya pengawasan dari badan-badan peradilan

Ibnu Khaldun membagi negara menjadi dua kelompok yaitu Negara dengan ciri kekuasaan alamiah (al-mulk al-thab $\left.\hat{\imath}^{\prime} \hat{\imath}\right)$ dan Negara dengan ciri kekuasaan politik (al-mulk al-siyâsî). Tipologi Negara pertama ditandai dengan kekuasaan sewenang-wenang, keunggulan dan kekuatan sangat berperan serta prinsip keadilan sangat diabaikan dan pada gilirannya akan membentuk suatu Negara yang tidak berperadaban. Sedangkan tipe negara yang kedua dengan ciri-ciri kekuasaan politik di kelompokkan menjadi tiga yaitu Negara hukum demokrasi (siyâsah dîniyah), Negara hukum sekuler (siyâsah ‘aqliyah) dan negara hukum republik ala Plato (siyâsah madaniyah). Negara hukum demokrasi Islam (siyâsah dîniyah) adalah Negara yang menjadikan syariah (hukum Islam) sebagai fondasi. Karaktersistik siyâsah dîniyah adalah selain al-Quran, hadist maka akal manusiapun sama-sama berperan dan berfungsi dalam kehidupan Negara.

Menurut Ibnu Khaldun, ${ }^{13}$ tipe Negara yang paling baik adalah siyâsah dîniyah karena siyâsah 'aqliyah (negara sekuler) hanya mendasarkan pada hukum sebagai hasil rasio manusia tanpa mengindahkan hukum dengan sumber wahyu. Sedangkan siyâsah madaniyah (ala republik Plato) merupakan suatu Negara yang diperintah oleh segelintir orang dari golongan elit atas sebagian besar golongan budak yang tidak mempunyai kekuatan politik.

Menurut Muhammad Tahir Azhary, 14 ada lima konsep Negara Hukum yang tentu memiliki kelemahan dan kelebihan, untuk itu berikut akan dipaparkan perbandingan antara kelima konsep Negara hukum tersebut sebagai berikut. ${ }^{15}$

\begin{tabular}{|c|c|c|}
\hline \multicolumn{3}{|c|}{ Perbandingan konsep Negara hukum } \\
\hline Konsep & Ciri-ciri & Unsur utama \\
\hline $\begin{array}{l}\text { Nomokrasi } \\
\text { Islam }\end{array}$ & $\begin{array}{l}\text { Bersumber dari Al Quran, } \\
\text { sunnah }\end{array}$ & $\begin{array}{l}\text { Sembilan prinsip: } \\
\text { Kekuasaan sebagai amanah }\end{array}$ \\
\hline
\end{tabular}

${ }^{13}$ Ibnu Khaldun, Muqaddimah, (Jakarta: Pustaka Al Kautsar, 2012)

14 Muhammad Tahir Azhari, Negara Hukum Suatu Studi tentang Prinsip Prinsipnya Dilihat Dari Segi Hukum Islam, Implementasinya pada Periode Negara Madinah dan Masa Kini, (Jakarta: Bulan Bintang, 1992) , 83

15 Ibid., 100-102 


\begin{tabular}{|c|c|c|}
\hline & $\begin{array}{l}\text { Nomokrasi bukan teokrasi- } \\
\text { persaudaraan } \\
\text { humanisme tan } \\
\text { kebebasan dalam arti positip }\end{array}$ & $\begin{array}{l}\text { Musyawarah } \\
\text { Keadilan } \\
\text { Persamaan } \\
\text { Pengakuan dan perlindungan } \\
\text { terhadap hak asasi manusia } \\
\text { Peradilan bebas } \\
\text { Perdamaian } \\
\text { Kesejahteraan } \\
\text { Ketaatan rakyat }\end{array}$ \\
\hline Konsep & Ciri-ciri & Unsur utama \\
\hline Rechtsstaat & $\begin{array}{lr}\text { Bersumber dari } & \text { rasio } \\
\text { manusia- } & \\
\text { liberalistik/individualistic- } \\
\text { humanisme r yang } \\
\text { antroposentrik } & \text { (lebih } \\
\text { dipusatkan pada manusia) } \\
\text { pemisahan antara agama } \\
\text { dan Negara secara mutlak- } \\
\text { ateisme dimungkinkan }\end{array}$ & $\begin{array}{l}\text { Menurut Stahl: } \\
\text { Pengakuan atau perlindungan } \\
\text { hak-hak asasi } \\
\text { Trias politika } \\
\text { Wetmating bestuur } \\
\text { Peradilan administrasi } \\
\text { Menurut Scheltema: } \\
\text { Kepastian hokum } \\
\text { Persamaan } \\
\text { Demokrasi, dan } \\
\text { Pemerintahan yang melayani } \\
\text { kepentingan umum }\end{array}$ \\
\hline Konsep & Ciri-ciri & Unsur utama \\
\hline Rule of law & $\begin{array}{l}\text { Bersumber dari rasio } \\
\text { manusia- } \\
\text { liberalistik/individualistik- } \\
\text { antroposentrik (lebih } \\
\text { dipusatkan pada manusia)- } \\
\text { pemisahan antara agama } \\
\text { dan Negara secara rigid } \\
\text { (mutlak)-freedom of religion } \\
\text { dalam arti positif dan } \\
\text { negative-ateisme } \\
\text { dimungkinkan }\end{array}$ & $\begin{array}{l}\text { Supremasi Hukum Equality } \\
\text { before the law } \\
\text { Individual rights. } \\
\text { Tidak memerlukan peradilan } \\
\text { administrasi Negara karena } \\
\text { peradilan umum dianggap } \\
\text { berlaku ungtuk semua orang, } \\
\text { baik warga biasa maupun } \\
\text { pejabat Pemerintah. Jika } \\
\text { rechtsstaat menekankan pada } \\
\text { peradilan administrasi. Maka } \\
\text { rule of law menekankan pada } \\
\text { equality before the law (unsur } \\
\text { ke 2) }\end{array}$ \\
\hline Konsep & Ciri-ciri & Unsur utama \\
\hline $\begin{array}{l}\text { Socialist } \\
\text { Legality }\end{array}$ & $\begin{array}{l}\text { Bersumber dari rasio } \\
\text { manusia-komunis-ateis- } \\
\text { totaliter-kebebasan } \\
\text { beragama yang semu dan } \\
\text { kebebasan propaganda anti } \\
\text { agama }\end{array}$ & $\begin{array}{l}\text { Perwujudan sosialisme } \\
\text { Hukum adalah alat di bawah } \\
\text { sosialisme } \\
\text { Penekanan pada sosialisme. } \\
\text { Realisasi sosialisme ketimbang } \\
\text { hak-hak perorangan }\end{array}$ \\
\hline Konsep & Ciri-ciri & Unsur utama \\
\hline Negara Hukum & Hubungan yang erat antara & Pancasila \\
\hline
\end{tabular}




\begin{tabular}{|l|l|l|}
\hline Pancasila & $\begin{array}{l}\text { agama dengan Negara- } \\
\text { bertumpu pada Ketuhanan }\end{array}$ & Sistem konstitusi \\
Yang Maha Esa-kebebasan & Persamaan \\
beragama dalam arti positif- & Peradilan bebas \\
ateisme tidak dibenarkan & \\
dan komunisme dilarang- & \\
& asas kekeluargaan dan & \\
kerukunan & \\
\hline
\end{tabular}

Bersumber dari perbandingan konsep Negara sebagaimana diuraikan di atas, perlu pula dijelaskan lebih lanjut perihal unsur yang utama di dalam nomokrasi Islam yaitu unsur kesejahteraan. Dalam pandangan Ibnu Khaldun, agama merupakan bagian dari kekuatan-kekuatan sosial yang sangat penting. Ibnu Khaldun tidak menyukai idealisme yang bersifat religius atau filosofis yang tidak menunjukkan fungsi sosial. ${ }^{16}$ Ibnu Khaldun sebagai salah satu ahli yang mengetengahkan teori kenegaraannya dapat dijadikan rujukan dalam hal ini karena Ibnu Khaldun juga mengungkapkan satu teori tentang kenegaraan yaitu yang dikenal dengan al-'ashabiyah wa aliqtishâd, yang secara popular dinamakan welfare state (Negara kesejahteraan). ${ }^{17}$

Dalam pandangan Islam, kesejahteraan bukan hanya ditentukan oleh terpenuhinya kebutuhan materiil, artinya dalam tingkat tertentu kesejahteraan meliputi kecukupan pemenuhan kebutuhan immaterial atau kebutuhan spiritual. Oleh karena itu pendapatan per kapita (GNP) bukanlah tujuan akhir dari sebuah negara. Jaminan bahwa semua investasi adalah halal, terpenuhinya kebutuhan spiritual dengan cara yang tidak bertentangan dengan syariat, terjaminnya kebebasan beribadah adalah parameter yang juga harus dipertimbangkan. Dengan demikian, yang dituju oleh Islam adalah sebuah bentuk kemajuan yang komprehensif meliputi kesejahteraan materiil dan spiritual. Sebuah negara yang tidak melakukan pelanggaran aturan-aturan syariat hanya karena ingin meraih apa yang dinamakan GNP atau ekonomi yang sifatnya material. ${ }^{18}$

\footnotetext{
16Andi Fariana, “Teori kebenaran menurut Al Ghazali dan Ibnu Khaldun, dalam perspektif Filsafat ilmu", Jurnal Komunike, Vol. 6, Nomor. (1 Juni 2014)

17 Agus Triyanta, Hukum Ekonomi Islam,dari politik hukum ekonomi Islam sampai pranata ekonomi syariah, ( Jogyakarta: FH UII Press, 2012), 11

18 Ibid., 89-90
} 
Menurut Muhammad Tahir Azhari, Indonesia menganut konsep Negara Hukum Pancasila yang berbeda dengan konsep barat pada umumnya. Beberapa ciri dari Negara Hukum Pancasila: (1) ada hubungan yang erat antara agama dan Negara. (2) Negara dan Hukum bertumpu pada Ketuhanan Yang Maha Esa. (3) Ada jaminan kebebasan beragama dalam arti positif. (4) Ateisme tidak dibenarkan dan komunisme dilarang. (5) Asas kekeluargaan dan kerukunan. Menurut M. Tahir Azhari, Indonesia tergolong sebagai Negara Nomokrasi yaitu Negara yang kekuasaannya di dasarkan pada hukum-hukum dari Tuhan. ${ }^{19}$

Menurut M. Tahir Azhari, ada dua hal yang perlu diperhatikan dalam negara hukum Pancasila. Pertama, adanya kebebasan beragama yang harus mengacu pada makna yang positif sehingga pengingkaran terhadap Tuhan Yang Maha Esa (atheisme) ataupun sikap yang memusuhi Tuhan Yang Maha Esa dilarang. Kedua, ada hubungan yang erat antara agama dan negara, karena itu baik secara rigid (mutlak) maupun secara nisbi (longgar) Negara Republik Indonesia tidak mengenal doktrin pemisahan antara agama dan Negara karena doktrin pemisahan antara agama dengan Negara sangat bertentangan dengan Pancasila dan UUD 1945.20

Menurut A. Hasjmy, agama dan negara memiliki hubungan yang bersifat simbiotik, dimana antara keduanya mempunyai hubungan timbal balik yang saling melengkapi dan menguntungkan. ${ }^{21}$ Menurut A. Hasjmy, dengan melaksanakan prinsip-prinsip Pancasila berarti sekaligus melaksanakan prinsipprinsip Islam. Oleh sebab itu, A Hasjmy dapat menerima konsep negara bangsa (nation state) tanpa harus menyebut negara Islam. ${ }^{22}$

Sistem hukum nasional yang nilai-nilainya berasal dari The Living Law (hukum yang hidup) dalam negara Indonesia yaitu hukum Islam, hukum adat, dan hukum Barat maka menjadi suatu keniscayaan jika masyarakat berharap nilai-nilai hukum Islam bukan hanya masuk menjiwai sistem hukum nasional tetap menjadi bagian

19 Muhammad Tahir Azhari, Negara Hukum Suatu Studi tentang Prinsip Prinsipnya Dilihat Dari Segi Hukum Islam, Implementasinya pada Periode Negara Madinah dan Masa Kini, (Jakarta: Bulan Bintang, 1992), 71-72

20 Ibid.

21 Sirajuddin, Politik Ketatanegaraan Islam, (Jogyakarta: Pustaka Pelajar, 2007), 4

22 Ibid, 17 
penting dalam sistem hukum yang dibangun. Salah satu bagian dari sistem hukum nasional tersebut adalah sistem hukum ekonomi dan bagiannya adalah sistem hukum ekonomi syariah yang saat ini terus berkembang dan dibangun. Di dalam membangun sistem hukum nasional maka diperlukan politik hukum.

Politik hukum Islam Indonesia memiliki berbagai dimensi dan hasilnya telah dilakukan transformasi nilai-nilai hukum Islam ke dalam hukum positif, seperti transformasi dalam UU Perkawinan (UU No. 1 Tahun 1974), UU Wakaf (UU No. 41 tahun 2004), UU Peradilan Agama (UU No. 3 Tahun 2006), UU tentang Surat Berharga Syariah Negara (UU No. 19 Tahun 2008), UU Perbankan Syariah (UU No. 21 Tahun 2008), UU Pornografi (UU No. 44 Tahun 2008), UU Pengelolaan Zakat (UU No. 23 Tahun 2011), kemudian transformasi dalam Kompilasi Hukum Ekonomi Syariah, dan transformasi dalam berbagai peraturan Bank Indonesia, Bapepam dan Surat Edaran Mahkamah Agung. Selain tingkat UU yang menunjukkan adanya transformasi Hukum Islam kedalam sistem hukum nasional adalah berbagai produk perundang-undangan berupa Peraturan Menteri, Peraturan Bank Indonesia atau Peraturan OJK serta Peraturan Mahkamah Agung yang merupakan sistem hukum ekonomi Islam dan merupakan bagian dari satu kesatuan sistem hukum yaitu bangunan sistem hukum nasional.

Sistem hukum ekonomi Islam jelas diwarnai oleh Fiqh dan diketahui bahwa perkembangan fiqh di Indonesia selain karena faktor budaya yang kondusif maka para dai (pendakwah) juga memiliki peran yang penting. Para dai kebanyakan bermadzhab Syafi'iyah dan memiliki paham serta cara dakwah yang sangat adaptif. Hal ini sesuai dengan kenyataan yang ada bahwa Negara Indonesia menganut sistem hukum terbuka (open legal system) ${ }^{23}$ yang artinya Negara menerima bahan baku hukum yang dibutuhkan dari mana saja, selama tidak bertentangan dengan nilai-nilai Pancasila dan UUD 1945. Di Indonesia sebelum merdeka berlaku tiga sistem hukum yaitu hukum adat, hukum Islam dan hukum Barat, namun setelah merdeka ketiga sistem hukum tersebut tetap menjadi bahan baku dalam pembentukan sistem hukum Nasional.

${ }^{23}$ Ija Suntana, Politik Hukum Islam, (Bandung: Pustaka Setia, 2014), 15 
Menurut Ismail Sunny, politik hukum Islam Indonesia adalah proses penerimaan hukum Islam sebagai sumber hukum oleh negara atau dengan kata lain bahwa politik hukum Islam Indonesia adalah kebijakan hukum (legal policy) yang akan atau telah dilaksanakan secara nasional oleh Pemerintah Indonesia. Politik hukum Islam meliputi pembangunan dan pembaharuan hukum terhadap materimateri hukum Islam agar sesuai dengan kebutuhan masyarakat. Termasuk di dalamnya memiliki pengertian atas pelaksanaan hukum Islam yang telah berlaku, penegakkan fungsi lembaga, dan pembinaan para penegak hukum Islam. ${ }^{24}$

Jika menelusuri lebih lanjut perihal pemberlakukan Hukum Islam di Indonesia, maka secara rinci ada lima teori yang dapat dipergunakan yaitu: 1 . Teori kredo, 2 . Teori Receptio in complex, 3. Teori Receptie, 4. Teori Receptie Exit dan 5. Teori Receptie A Contrario

\section{Urgensi Fatwa MUI dalam Pembangunan Sistem Hukum Ekonomi Islam}

Fatwa adalah sebuah istilah mengenai pendapat atau tafsiran pada suatu masalah yang berkaitan dengan hukum Islam. Fatwa dalam bahasa Arab berarti nasihat, petuah, jawaban atau pendapat. Adapun yang dimaksud adalah sebuah keputusan atau nasihat resmi yang diambil oleh sebuah lembaga atau perorangan yang diakui otoritasnya, disampaikan oleh seorang mufti atau ulama, sebagai tanggapan atau jawaban terhadap pertanyaan yang diajukan oleh peminta fatwa (mustaftî) yang tidak mempunyai keterikatan. Penggunaannya dalam kehidupan beragama di Indonesia, fatwa dikeluarkan oleh MUI sebagai suatu keputusan tentang persoalan ijtihâdiyah yang terjadi di Indonesia guna dijadikan pegangan. ${ }^{25}$ Sementara sumber hukum Islam terdiri dari al-Quran, al-Sunnah, dan $r a^{\prime} y$ (akal fikiran manusia) dengan berbagai metode diantaranya adalah ijma, qiyas, istihsan, istishab, al-masalih al-mursalah, dan 'urf. Ijma' adalah persetujuan atau kesesuaian pendapat para ahli mengenai masalah pada suatu tempat di suatu masa. Dengan demikian fatwa merupakan ketentuan hukum Islam yang diterbitkan berdasarkan pemikiran dan ijtihad dengan cara ijma'. Namun, fatwa

\footnotetext{
${ }^{24}$ Ibid., 16

25Id.m. Wikipedia.org., Pengertian fatwa, diakses 7 Maret 2017.
} 
tidak sama persis dengan ijma karena didalam ijma telah terjadi kesepakatan/tidak ada perbedaan pendapat atas suatu masalah (yang diminta ataupun tidak diminta).

Kita sadari bahwa kondisi obyektif berkaitan dengan permasalahan manusia terus berkembang dan memerlukan tanggapan logis yuridis yang berasal dari nash-nash al-Quran dan alSunnah. Pencarian jawaban atas berbagai permasalahan yang muncul dengan menggunakan rujukan al-Quran dan al-Sunnah memerlukan ijtihad dengan syarat dan ketentuan tertentu. Orang yang tidak memiliki kemampuan dan memerlukan jawaban atas suatu masalah bisa menempuh satu jalur yaitu dengan cara meminta penjelasan hukum atau meminta fatwa. Fatwa selain dapat memberikan solusi atas pertanyaan yang diajukan, dapat juga berfungsi sebagai respon atas perkembangan permasalahan yang bersifat kekinian atau kontemporer karena masyarakat membutuhkannya sesuai dengan perkembangan dan perubahan zaman. ${ }^{26}$

Kedudukan mufti dihadapan umat sama seperti kedudukan Nabi dihadapan umat Islam, karena sebagaimana hadis Rasulullah bahwa "Ulama adalah ahli waris para Nabi". Arti pentingnya ulama karena ulama menggantikan kedudukan Rasulullah dalam menyampaikan hukum-hukum syariat, mengajar manusia dan memberi peringatan kepada mereka dan mufti menggantikan Nabi dalam memutuskan hukum-hukum yang digali dari dalil-dalil hukum melalui analisis dan ijtihad mereka sehingga berdasarkan hal ini maka mufti kedudukannya sangat penting sebagaimana disebutkan oleh al-Syâtibî bahwa mufti merupakan pencetus hukum yang wajib diikuti dan dilaksanakan keputusannya, dan didalam melaksanakan tugasnya memberikan fatwa, MUI memiliki pedoman dasar dan prosedur yang dirumuskan dialam Keputusan No. U596/MUI/X/1997 yang ditetapkan pada tanggal 2 Oktober 1997.27 Untuk memperjelas dasar-dasar dalam memberikan fatwa, berikut rincian dimaksud:

${ }^{26}$ Huzaemah T. Yanggo, Urgensi fatwa pada zaman sekarang, makalah disajikan dalam seminar Hukum Islam di Universitas Indonesia, (Depok, Jawa Barat tanggal 9 februari 2017)

27ibid 
a. Setiap keputusan fatwa harus mempunyai dasar atas kitabullah dan sunnah rasul yang mu'tabarak serta tidak bertentangan dengan kemashlahatan umat

b. Jika tidak terdapat dalam Kitabullah dan Sunah Rasul sebagaimana ditentukan pada Pasal 2 Ayat 1, Keputusan Fatwa hendaklah tidak bertentangan dengan ijma, qiyas yang mu'tabar dan dalil-dalil hukum yang lain seperti istihsân, maslahah mursalah dan saddu al dzari'ah.

c. Sebelum pengambilan keputusan fatwa, hendaklah ditinjau pendapat-pendapat para imam madzhab terdahulu, baik yang berhubungan dengan dalil-dalil hukum yang berhubungan dengan dalil yang dipergunakan oleh pihak yang berbeda pendapat

d. Pandangan tenaga ahli dalam bidang masalah yang akan diambil keputusan fatwanya, dipertimbangkan

Didalam Pasal 1 angka 2 UU No. 12 Tahun 2011 tentang Pembentukan Peraturan Perundang Undangan disebutkan bahwa Peraturan Perundang Undangan adalah peraturan tertulis yang memuat norma hukum yang mengikat secara umum dan dibentuk atau ditetapkan oleh lembaga negara atau pejabat yang berwenang melalui prosedur yang ditetapkan dalam peraturan perundangundangan. Berkaitan dengan bunyi Pasal 1 angka 2 ini maka yang dimaksud dengan hierarki Perundang-Undangan adalah:

a. Undang Undang Dasar Negara Republik Indonesia Tahun 1945

b. Ketetapan Majelis Permusyawaratan Rakyat

c. Undang Undang/Peraturan Pemerintah Pengganti Undang Undang

d. Peraturan Pemerintah

e. Peraturan Presiden

f. Peraturan Daerah Provinsi

g. Peraturan Daerah Kabupaten/kota

Selain hierarki Peraturan Perundang-Undangan sebagaimana disebut diatas, beberapa peraturan perundang undangan lain seperti

a. Peraturan yang ditetapkan oleh MPR

b. Peraturan yang ditetapkan oleh DPR

c. Peraturan yang ditetapkan oleh DPD

d. Peraturan yang ditetapkan oleh Mahkamah Agung 
e. Peraturan yang ditetapkan oleh Mahkamah Konstitusi

f. Peraturan yang ditetapkan oleh Badan Pemeriksa Keuangan

g. Peraturan yang ditetapkan oleh Komisi Yudisial

h. Peraturan yang ditetapkan oleh Bank Indonesia

i. Peraturan yang ditetapkan oleh Menteri

j. Peraturan yang ditetapkan oleh badan lembaga atau komisi yang setingkat yang dibentuk dengan Undang Undang atau Pemerintah atas perintah Undang Undang

k. Peraturan yang ditetapkan oleh Dewan Perwakilan Rakyat Daerah Provinsi

1. Peraturan yang ditetapkan oleh Gubernur

m. Peraturan yang ditetapkan oleh Dewan Perwakilan Rakyat Daerah/kota

n. Peraturan yang ditetapkan oleh Bupati/ Walikota

o. Peraturan yang ditetapkan oleh Kepala Desa atau yang setingkat

Mencermati peraturan yang dapat dikeluarkan oleh lembaga negara sebagaimana disebut diatas maka fatwa MUI tidak merupakan salah satu dari produk peraturan perundang-undangan sehingga fatwa MUI bukan peraturan yang mengikat karena MUI merupakan organisasai alim ulama umat Islam dan bukan merupakan institusi milik Negara, bahkan fatwa MUI bukan merupakan hukum negara yang bisa dipaksakan dan tidak memiliki sanksi dan harus ditaati oleh seluruh warganegara. ${ }^{28}$ Menurut Mahfud MD, fatwa MUI merupakan pendapat keagamaan, bukan hukum positif yang boleh diikuti dan boleh tidak diikuti sehingga mereka yang melanggar fatwa MUI tidak boleh diberi sanksi atau hukuman. Fatwa itu mengikat pada diri sendiri dan tidak diatur dalam UU.29 Namun, dalam kenyataannya fatwa MUI seringkali menjadi pedoman dalam berbagai aktivitas bermasyarakat karena fatwa MUI (khususnya bagi umat Islam) merupakan sikap keagamaan yang penting diperhatikan

${ }^{28}$ Ainun Najib, "Fatwa Majelis Ulama Indonesia dalam Perspektif Pembangunan Hukum Responsif", Jurnal Fak Syariah IAIN Ibrahimiy, Volume 4, No.2, (Desember 2012), 375

${ }^{29}$ Moh. Mahfud, MD, “Apakah fatwa MUI harus diikuti?”, Detiknews, (17 Januari 2017) 
dan dapat menjadi pedoman. Hal ini khususnya dalam aktivitas ekonomi syariah.

Keberadaan fatwa MUI tidak dapat dipandang sebelah mata. Banyak fatwa MUI (dalam hal ini yang dikeluarkan oleh DSN-Dewan Syariah Nasional yang dibentuk oleh MUI pada tahun 1998 berdasarkan SK Dewan Pimpinan MUI No. Kep-754/MUI/II/1999 yang intinya dibentuk dengan tugas dan kewenangan untuk memastikan kesesuaian antara produk, jasa, dan kegiatan usaha bank dengan prinsip syariah) yang telah ditransformasi ke dalam peraturan perundang-undangan seperti Peraturan Bank Indonesia dan Peraturan Otoritas Jasa Keuangan yang dipergunakan untuk mengatur aktivitas ekonomi syariah.

Selain itu, saat ini dirasakan bahwa keabsahan produk (khususnya dalam perbankan syariah) belum cukup memadai secara formel maupun substansi untuk mewujudkan kepastian hukum bagi para pihak yang melakukan transaksi. ${ }^{30}$ Selain transformasi fatwa MUI ke dalam peraturan perundang-undangan yang dengan tujuan agar bersifat mengikat dan ditaati bagi seluruh pelaku bisnis dalam ekonomi syariah, dalam kenyataannya banyak fatwa MUI yang belum ditransformasikan kedalam peraturan Perundang Undangan namun telah dijadikan rujukan dan pedoman dalam operasionalisasi aktivitas perbankan syariah yang secara internal dipergunakan atas rekomendasi dan pengawasan dari DPS (Dewan Pengawas Syariah) yang ada pada masing-masing bank syariah. ${ }^{31}$ Hal ini mengingatkan pada konsep hukum yang dibangun oleh Kusumaatmadja bahwa hukum adalah keseluruhan kaedah dan asas yang mengatur kehidupan manusia dalam masyarakat termasuk lembaga dan proses didalam mewujudkan berlakuknya hukum dalam kenyataan. ${ }^{32}$

30Setiawan Budi Utomo, “Kajian Hukum Atas Keabsahan Produk Perbankan Syariah Dikaitkan Dengan Fatwa Dewan Syariah Nasional Dalam Tujuan Negara Kesejahteraan" (Disertasi Program Doktor Ilmu Hukum Unpad Bandung , 2011), 267 dan 492

${ }^{31}$ Giyantoro, pelaku bisnis perbankan syariah dalam diskusi di Pascasarjana ABFII Perbanas tanggal 25 Februari 2017

${ }^{32}$ Neni Sri Imaniyati, Aspek Hukum Peluang dan Tantangan Perbankan Syariah di Era Masyarakat Ekonomi Asean, makalah disajikan dalam Semiloka Nasional Hukum Ekonomi Syariah (Bandung, 20-21 Desember 2016) 
Fatwa MUI merupakan kaedah dan asas yang dianggap penting dan diperlukan dalam rangka memperlancar aktivitas ekonomi syariah, apakah bentuknya telah ditransformasi kedalam peraturan perundang-undangan ataupun belum ditransformasikan. Cepatnya pertumbuhan bisnis syariah khususnya pertumbuhan perbankan syariah menimbulkan konsekuensi lahirnya berbagai kebutuhan yang berkaitan dengan kejelasan dalam berbagai masalah fiqih dan fatwa MUI merupakan solusi yang dianggap mampu memberikan pedoman dan rujukan. Fatwa memiliki kedudukan yang penting di dalam Hukum Islam walaupun fatwa bersifat ikhtiyâriyah (tidak mengikat secara legal, mengikat secara moral khususnya bagi mustaft $\hat{\imath}$ /pihak yang meminta fatwa). Fatwa merupakan hasil ijtihad kolektif sekalipun demikian fatwa tidak bisa disamakan dengan ijma dan didalam sistem hukum positif, fatwa tidak mengikat dan agar bisa bersifat mengikat maka fatwa harus melewati proses legislasi terlebih dahulu. ${ }^{33}$

Beberapa substansi UU dan Rancangan Undang-Undang disusun dengan melibatkan pemikiran dari para ulama. Salah satunya yang dapat dijadikan contoh adalah UU tentang Wakaf. Didalam menanggapai berbagai wacana tentang wakaf dan dengan adanya permohonan fatwa dari Departemen Agama (2002) tentang wakaf uang maka MUI merespon dengan mengeluarkan fatwa tentang wakaf uang. Hal ini menunjukkan urgensi dari fatwa, bukan hanya memberi muatan dalam substansi suatu undang-undang tetapi seringkali fatwa menjadi substansi dalam berbagai produk perundang-undangan sehingga fatwa menjadi materi dalam pembentukan perundang undangan dan dalam rangka mewujudkan masyarakat yang berkualitas (ghayra ummah) dan negara yang aman, damai, adil dan makmur rohaniah dan jasmaniah yang diridhoi Allah maka keberadaan MUI merupakan hal yang penting sebagaimana tujuan berdirinya MUI itu sendiri. ${ }^{34}$

Selain fatwa memberi warna penting dalam substansi berbagai produk hukum maka fatwa MUI juga memberikan arti penting dalam

${ }^{33}$ M. Erfan Riadi, “Kedudukan Fatwa ditinjau dari Hukum Islam dan Hukum Positif (Analisis Yuridis Normatif)," Jurnal Ulumuddin, Vol. VI, Tahun IV, (Januari-Juni 2010) ${ }^{34}$ Asrul Sani, Fatwa MUI dalam Legislasi di Indonesia, Makalah disajikan dalam Seminar Nasional di Universitas Indonesia, (Depok Jawa Barat, 9 Februari 2017) 
putusan hakim di Pengadilan (khususnya Pengadilan Agama), dan putusan pengadilan merupakan bagian penting dari bangunan sistem hukum. Diketahui bahwa belum semua peraturan Hukum Islam ditransformasi menjadi peraturan perundang undangan, oleh sebab itu Undang-Undang (UU Kekuasaan Kehakiman Pasal 5 ayat 1) mewajibkan hakim untuk menggali, mengikuti dan memahami nilanilai yang hidup dalam masyarakat, dan pengadilan dilarang menolak untuk memeriksa, mengadili dan memutus perkara yang diajukan dengan dalih bahwa hukum tidak ada atau kurang jelas, melainkan hakim wajib memeriksa dan mengadilinya. Selain itu, hakim dalam memutus perkara harus memuat alasan dan dasar putusan, serta hakim dalam menyelesaikan perkara wajib memperhatikan nilai-nilai hukum yang hidup dalam masyarakat sehingga utusannya sesuai dengan rasa keadilan. Berdasarkan hal tersebut maka sepantasnyalah hakim dalam memutuskan perkara juga merujuk kepada berbagai kitab fiqih dan fatwa para ulama (antara lain fatwa yang dikeluarkan oleh MUI).

Dalam praktek peradilan, fatwa MUI senantiasa menjadi rujukan sebagai sumber hukum tak tertulis dalam memeriksa dan mengadili perkara. Bahkan sesuai dengan Peraturan Mahkamah Agung Nomor 14 Tahun 2016 tanggal 22 Desember 2016 tentang tatacara penyelesaian perkara sengketa ekonomi syariah, terdapat ketentuan yang lebih tegas tentang pentingnya argumentasi dalil-dalil syariah sebagai landasan yuridis, filosofis dan religius putusan peradilan agama. Pada Pasal 5 disebutkan bahwa segala putusan dan penetapan pengadilan dalam bidang ekonomi syariah selain harus memuat alasan dan dasar putusan juga harus memuat prinsip-prinsip syariah yang dijadikan dasar untuk mengadili, sementara pada Pasal 1 angka 2 disebutkan bahwa prinsip syariah adalah prinsip hukum Islam dalam kegiatan ekonomi syariah berdasarkan fatwa yang dikeluarkan oleh lembaga yang memiliki kewenangan dalam penetapan fatwa dibidang syariah. ${ }^{35}$ Penjelasan ini menunjukkan bahwa fatwa pada lembaga peradilan mendudukan fatwa sebagai pedoman tidak tertulis dalam menjadikan dasar putusan suatu

${ }^{35}$ Mukti Arto, Fatwa MUI sebagai Sumber Penemuan Hukum Dalam Putusan Hakim, Makalah disajikan dalam Seminar di Universitas Indonesia, (Depok, jawa Barat 9 Februari 2017) 
perkara khsusunya perkara ekonomi syariah atau sebagai sumber bagi hakim dalam menemukan hukum.

Kedua contoh diatas, baik fatwa yang mewarnai substansi suatu undang-undang atau produk perundang-undangan dan fatwa dalam proses penemuan hukum di pengadilan menjadi suatu keniscayaan di Indonesia yang berdasarkan kepada Ketuhanan Yang Maha Esa dimana tidak ada pemisahan antara negara dengan agama dan hukum Islam merupakan hukum yang hidup dan tumbuh di dalam masyarakat Indonesia sehingga menjadikan fatwa sebagai suatu jalan bagi terjadinya transformasi hukum Islam kedalam hukum positif melalui mekanisme politik hukum Islam.

Dalam rangka mempercepat transformasi Hukum Islam ke dalam hukum positif sesuai dengan bidang-bidang yang diperlukan, selain pentingnya politik hukum Islam maka penguatan kelembagaan juga penting dilakukan. Lembaga-lembaga tersebut antara lain, Pengadilan Agama, DSN-MUI dan DPS, Basyarnas, notaris bahkan juga OJK. Penguatan kelembagaan merupakan aplikasi dari teori yang dikemukakan oleh L. Friedman bahwa hukum sebagai sistem meliputi substansi, kultur dan struktur. Upaya memperkuat kelembagaan tidak bisa lepas dari upaya membangun kultur yang baik yaitu melalui lembaga pendidikan dan para ulama termasuk para praktisi ekonomi Islam dan penegak hukumnya (semua hal ini merupakan bagian dari sasaran yang harus dibidik dalam politik hukum Islam). Untuk memperjelas seutuhnya gambaran sebagaimana diuraikan diatas, berikut disusun skema sebagai bentuk alur yang menunjukkan urgensi fatwa dalam pembentukan sistem hukum ekonomi Islam.

\section{Penutup}

Fatwa memang bukan merupakan salah satu bentuk peraturan perundang-undangan sebagaimana hirarki dalam tata aturan hukum positif yang memiliki kekuatan mengikat bagi seluruh warganegara, namun fatwa dapat memiliki kekuatan mengikat setelah ditransformasi ke dalam hukum positif menjadi berbagai bentuk Peraturan Perundang-Undangan sesuai dengan kebutuhan. Dalam kenyataannya, fatwa yang dikeluarkan oleh DSN-MUI (Dewan Syariah Nasional Majelis Ulama Indonesia) telah cukup banyak yaitu sekitar kurang lebih 107 fatwa dan telah memberi kontribusi positif 
terhadap regulasi dalam sistem hukum ekonomi syariah. Seiring dengan pertumbuhan ekonomi syariah maka fatwa dari DSN-MUI terus dibutuhkan karena menjadi bagian yang penting dalam bangunan sistem hukum ekonomi syariah, untuk itu perlu terus dijaga agar tetap kondusif politik hukum Islam yang menjadi katalisator dalam mentransformasi nilai-nilai hukum Islam yang merupakan salah satu dari the living law untuk pada akhirnya dapat melahirkan sistem hukum ekonomi Islam yang komprehensif dan dapat dijadikan pedoman bagi setiap pelaku ekonomi syariah.

\section{Daftar Pustaka}

Alamsyah, Halim, (Deputi Gubernur BI), Perkembangan dan Prospek Perbankan Syariah Indonesia, Tantangan Dalam Menyongsong MEA 2015, makalah disajikan dalam ceramah ilmiah IAEI, (Jakarta 13 April 2012).

Arto, Mukti, Fatwa MUI sebagai Sumber Penemuan Hukum Dalam Putusan Hakim, Makalah disajikan dalam Seminar di Universitas Indonesia, (Depok Jawa Barat 9 Februari 2017)

A.V Dicey, An Introduction to Study of Law of The Constitution, (London: Mac Millan \& Co., 1959)

Azhari, Muhammad Tahir, Negara Hukum Suatu Studi tentang Prinsip Prinsipnya Dilihat Dari Segi Hukum Islam, Implementasinya pada Periode Negara Madinah dan Masa Kini, (Jakarta: Bulan Bintang, 1992).

Fariana, Andi. "Teori kebenaran menurut Al Ghazali dan Ibnu Khaldun, dalam perspektif Filsafat ilmu", Jurnal Komunike, Vol. 6, Nomor. 1 (Juni 2014).

Fauzi, Yuslam, Prospek Ekonomi Syariah, Makalah disajikan dalam seminar IAEI bekerjasama dengan ABFII Perbanas, (Jakarta, 20 Februari 2013)

Giyantoro, pelaku bisnis perbankan syariah dalam diskusi di Pascasarjana ABFII Perbanas tanggal 25 Februari 2017

Huda, Ni'matul, Negara Hukum, Demokrasi dan Judicial Review, (Jogyakarta: UII Press, 2005)

Hartono, Sunaryati, Politik Hukum Menuju Satu Sistem Hukum Nasional, (Bandung: Alumni, 1991) 
Hartono, Sunaryati, Bhineka Tunggal Ika sebagai Asas Hukum Bagi Pembangunan Hukum Nasional, (Bandung: Citra Aditya Bakti, 2006)

Imaniyati, Neni Sri, Aspek Hukum Peluang dan Tantangan Perbankan Syariah di Era Masyarakat Ekonomi Asean, Makalah disajikan dalam Semiloka Nasional Hukum Ekonomi Syariah, (Bandung, 20-21 Desember 2016)

Khaldun, Ibnu, Mukadimah, (Jakarta: Pustaka Al Kautsar, 2012)

Mahfud, Moh. MD, "apakah fatwa MUI harus diikuti?", Detiknews, (17 Januari 2017)

Martowardoyo Agus (Gubernur Bank Indonesia), Syariah Economic Festival, Surabaya, kompas, .co.id, 27 Oktober 2016

Najib, Ainun. "Fatwa Majelis Ulama Indonesia dalam Perspektif Pembangunan Hukum Responsif". Jurnal Fak Syariah IAIN Ibrahimiy, Volume 4, No.2, (Desember 2012).

Permana K. Achmad (Sekretaris Jenderal Asbisindo), compass.co.id, 21 November 2016

Riadi, M. Erfan, "Kedudukan Fatwa ditinjau dari Hukum Islam dan Hukum Positif (analisis yuridis normatif)", Jurnal Ulumuddin, Voume VI, Tahun IV, (Januari-Juni 2010)

Sabine, George, A History of Political Theory, (London: George G. Harrap \& CO.Ltd., 1995)

Sani, Asrul, fatwa MUI dalam Legislasi di Indonesia, Makalah disajikan dalam Seminar Nasional Fatwa MUI, Universitas Indonesia, (Depok Jawa Barta,9 Februari 2017)

Soekanto, Soerjono, Penelitian Hukum Normatif, (Jakarta: Raja Grafindo Persada, cetakan 14, juni 2012)

Soemantri, Sri, Bunga Rampai Hukum Tata Negara Indonesia, (Bandung, PT Alumni, 1992)

Suntana, Ija, Politik Hukum Islam, (Bandung: Pustaka Setia, 2014).

Sirajuddin, Politik Ketatanegaraan Islam, (Jogyakarta: Pustaka Pelajar, 2007)

Syaukani, Imam Syaukani dan A. Ahsin Thohari, Dasar-dasar politik hukum, (Jakarta: Raja Grafindo Persada, 2004).

Thalib, Dahlan, Kedaulatan Rakyat Negara Hukum dan Hak-hak Asasi Manusia, Kumpulan Tulisan dalam rangka 70 Tahun Sri Soemantrri Martosoewignyo, (Jakarta: Media Pratama, 1996) 
Triyanta, Agus, Hukum Ekonomi Islam,dari politik hukum ekonomi Islam sampai pranata ekonomi syariah, (Jogyakarta: FH UII Press, 2012)

Utomo, Setiawan Budi, Kajian Hukum Atas Keabsahan Produk Perbankan Syariah Dikaitkan Dengan Fatwa Dewan Syariah Nasional Dalam Tujuan Negara Kesejahteraan (Disertasi Program Doktor Ilmu Hukum Unpad Bandung, 2011)

Yanggo, T. Huzaemah, Urgensi fatwa pada zaman sekarang, makalah disajikan dalam seminar Hukum Islam di Universitas Indonesia, (Depok Jawa Barat, 9 februari 2017)

Wikipedia.org. Pengertian fatwa, diakses 7 Maret 2017 